\title{
The rise of anchor countries
}

\section{A New Global Shift challenging economic geography}

In his influential book "Global Shift", Peter DiCKEN (2003, 2007; quotes in the following are taken from the $4^{\text {th }}$ edition 2003) describes recent trends in the global economic division of labour which have specific impact on the relationships between core and periphery of the world economy. Dicken argues that spaces "shrink" due to progress in information, communication and transport technologies. Production processes increasingly are fragmented, and complex organizational patterns of global value chains emerge, with more demanding production processes relocating from core to periphery (9). Despite such relocations he concludes that "the developed countries are clearly 'winners' in the global economy" (524) whereas, "with one or two exceptions among the NIEs [Newly Industrialized Economies, T.A.], industrial growth has done little to reduce the severe problems of unemployment and underemployment - with their resulting poverty - in developing countries." (562).

In recent years, a new quality of globalization is taking shape. This New Global Shift is challenging Dicken's analysis in three ways:

First, a new group of drivers of global change is emerging. Following STAMM (2004) we will call this group "anchor countries". Anchor countries are the largest economies of their respective developing world region - e.g. China as the dominant economy of East Asia, India and Pakistan in South Asia, Brazil and Argentina in South America, Mexico in Central America and the Caribbean, South Africa and Nigeria in Sub-Saharan Africa. ${ }^{1}$ Many of these economies grow at an enormous pace. Most notably, China's growth has exceeded $8 \%$ per year for almost three decades. Since 2003, India, Argentina, Nigeria, Pakistan, Russia, and Turkey all grow at average rates higher than 7 $\%$ per annum; Indonesia, Iran, Thailand and Saudi Arabia are only slightly less dynamic (see Altenburg/ LeININGER 2008). Given this combination of size and growth, these coun- tries have a huge impact on their region, and in many cases even on global development trends. The anchor-country-concept highlights this role as influential economic and political actors in the respective world region or even at a global scale. This distinguishes it from other concepts such as threshold countries or newly industrialized countries - countries of these groupings may be more developed, but less influential because of their limited size and lack of international voice.

Second, the emergence of anchor countries challenges the existing world economic and political order. For many decades, and until very recently, the dichotomy between the industrialized and wealthy nations of the OECD and the less productive poor nations of Africa, Latin America and Asia had shaped world economy and world politics. Although a few formerly poor countries previously caught up with the developed countries of Western Europe and North America - most notably Japan after World War II, Korea, Taiwan and Singapore since the mid 1960s, and more recently some countries of the European periphery (Spain, Ireland) - this did not challenge the dominance and welfare of the established centres of the world economy. The recent economic catch-up of anchor countries is different because of the size of their economies. According to growth projections, none of the European economies would be among the six largest economies of the world by 2050 . In addition, some of the anchor countries (e.g. Brazil, China, India) are progressing rapidly in terms of technology-intensive production and exports, thereby challenging the technological hegemony of the old industrialized countries. Likewise, Western dominance is eroding in world politics. In recent years, the emerging powers loudly claim - and in fact achieve - more influence in international decision-making bodies such as the UN Security Council, the G8, the World Trade Organisation (WTO), and the International Monetary Fund (IMF). 
Third, the economic success of some of the largest and most populated developing countries is reducing poverty at a pace that is unprecedented in history. The recent growth process already shifted hundreds of millions of people out of poverty, particularly in China. Similar developments are likely to occur if India, Nigeria, Pakistan, Indonesia and other poor and population-rich countries sustain their current economic dynamism. Moreover, the anchor countries have indirect poverty-reducing effects on other developing regions. Particularly China's and India's demand for oil and mineral resources has greatly increased commodity prices and created a bonanza for resource-exporting countries. As a consequence, Africa and Latin America are currently experiencing the strongest growth period since the 1970s.

The New Global Shift, strongly propelled by the anchor countries, thus brings about radically new patterns in the organization of global space. Most importantly, centre-periphery relationships need to be redefined. The NorthSouth divide between developed and underdeveloped countries had until recently been perceived as almost insurmountable. Now dynamic regional economies are emerging outside the Triad region. In global politics, the unipolar world - with the United States as the only remaining superpower after the collapse of the Soviet Union - is giving way to a multipolar world order, where China, India, Brazil and other developing countries increase their influence. In almost any field of global concern - peace and security, climate change, the protection of biodiversity - anchor countries have an increasing share in the causation of problems and are indispensable partners in the search for collaborative solutions.

The New Global Shift is increasingly attracting the attention of researchers in political sciences (particularly international relations) and economics. $^{2}$ Strikingly, it has not yet created much interest among economic geographers, despite the manifold implications for the spatial patterns of economic and political organization at the global, national, and sub-national levels With this special issue of Zeitschrift für Wirtschaftsgeographie we intend to change this situation. The following five articles illustrate the relevance of anchor countries as emerging players in different policy arenas, showing that the related global change dynamics lead to particular geographical configura- tions in different places. It brings together contributions by geographers, economists, political scientists and sociologists who all focus on the spatial implications of the rise of anchor countries in different policy fields. In the first article, Altenburg and Leininger introduce the anchor-country-concept and highlight how the economic and political rise of anchor countries brings about an unprecedented global power shift. The authors provide a framework for the analysis of their regional and global impact and discuss the trole of anchor countries role in two major fields: world economy and global security policy. Further, they explore how the heightened importance in these fields is mirrored in greater influence in key institutions of global governance. Richerzhagen and Scholz use the example of China to show how anchor countries have become key players in mitigating global environmental change. While advancing economic growth, China faces severe environmental degradation and over-exploitation of natural resources. China is a heterogeneous country, and specific regional environmental problems require decentralized coping strategies as well as appropriate national coordinating mechanisms. The analysis however shows a severe lack of horizontal and vertical policy coordination. The third article by Chevalier, von Drachenfels and Stamm addresses the question to what extent the new India-Brazil-South Africa (IBSA) Dialogue Forum may be seen as the beginning of substantial South-South partnerships among anchor countries. IBSA was initiated as an alliance of three emerging democracies jointly intending to push forward reforms in the global governance architecture. In addition, the three countries agreed to boost their trade and investment relations as well as their cooperation in science and technology. The authors show that that the commercial linkages are indeed developing rapidly, whereas the scientific and technology cooperation has not yet materialized. Finally, Humphrey and Schmitz analyse China's differential impact on other developing economies in Asian. The article distinguishes three groups of countries with different levels of technological development and different degrees of trade integration with China. It shows that China sources intermediate products from the East and Southeast Asian region on a significant scale. Via this mechanism, its own growth has created positive spillover effects into other Asian countries. Some poorer countries such as Laos, Cambodia and Myanmar however trade 
relatively little with China, and the existing trade may undermine long-term growth prospects because local firms are not well prepared to cope with more efficient Chinese competitors.

Tilman Altenburg, Bonn

\section{Notes}

1 "Developing world regions" are delimited according to the World Bank classification. Anchor countries are the largest economies of each of these regions plus those secondary economies that account for at least $20 \%$ of the remaining regional GDP.

2 See e.g. the special issue of World Development 2/2008 on the effects of China's and India's rise; see also HURRELL 2000.

\section{Literature}

Altenburg, T./Leininger, J.(2008): Global shifts caused by the rise of anchor countries. In: Zeitschrift für Wirtschaftsgeographie, (52)1.

DiCKEN, P. (2003): Global Shift: Reshaping the global economic map in the 21 st century. London a.o. $\left(4^{\text {th }}\right.$ edition).

DiCKEN, P. (2007): Global shift: Mapping the changing contours of the world economy. London a.o. ( $5^{\text {th }}$ edition).

Hurrell, A./CoOper, A.F. / GonZalez, G./ Ubiraci, R./ Sitaraman, S. (2000): Paths to power. Foreign policy strategies of intermediate states. Washington D.C. (Woodrow Wilson International Center, Working Paper Nr. 244).

Stamm, A. (2004): Schwellen- und Ankerländer als Akteure einer globalen Partnerschaft. Bonn. (DIE Discussion Paper 1/2004). 